\title{
Pallasia murata, n. sp.: a new British Sabellarian.
}

\author{
By
}

E. J. Allen, D.Sc.

Director of the Plymouth Laboratory of the Marine Biological Association.

With Plate X.

Fragments of a large tube built of pieces of coarse gravel and shell, evidently the work of some Polychæte, have been constantly dredged for many years on the grounds in the neighbourhood of the Mewstone and Stoke Point, to the eastward of Plymouth Sound. Not until June 4th, 1903, was the worm first discovered to whose skill as a mason these tubes are due. On that day the Laboratory fisherman captured and drew attention to a tube which was occupied by a living worm. The specimen, along with a number of fragments of empty tube, was obtained on a patch of coarse gravel off Stoke Point.

The species thus discovered has proved to belong to the genus Pallasia, a genus which was founded by de Quatrefages to include certain foreign Hermellidæ (Sabellaridæ) which were distinguished by having two rows and not three of peristomial chætæ in the paleal crown. As will be seen from the description given below, the new worm most closely resembles Pallasia Giardi, McIntosh, from Port Jackson, in Australia, and Pallasia laevispinis, Grube, from Upolu, in the Pacific and from Ascension. The details of its structure, as well as the large size of the British specimen, indicate that it is a new species. I propose to name it Pallasia murata. My thanks are due to Mrs. L. E. Sexton for the excellent drawings of the specimen reproduced in Plate X.

Tube. The pieces of tube of Pallasia which have been dredged have sometimes reached a length of four to five inches, with an internal diameter of half an inch. It is doubtful, however, whether a complete tube has ever been obtained.

The tube is built of two layers, an internal layer consisting of comparatively small pieces of shell or thin, flat stones, arranged with considerable regularity and forming a smooth internal surface, and an external layer of large pieces of gravel and shell, forming a strong, but 
rugged and irregular, outer covering. (Plate X., Fig. 5). The particular tube which contained the living worm had a piece of Halecium halecinum growing near one end. This circumstance, combined with the fact that short pieces of empty tube only are generally taken with the dredge, seems to suggest that the tubes are sunk more or less vertically in the gravel, with one end protruding at the surface.

Colour. When removed from its tube the general colour of the body of the worm is seen to be buff, with dark chocolate-brown markings in the region of the thorax and peristomium. The branchiæ, which form two rows along the dorsal surface of the thorax, are dark olive-green, and the smooth caudal portion of the animal is also dark green.

External characters (Figs. 1 and 2). The peristomial lobes, which carry the crown of paleæ, are not fused together as in Sabellaria, but form distinct, elongated organs, pointed at their anterior extremities. Their dorsal surfaces are slightly concave, and each carries a row of a little over twenty papillæ on its external margin, and two rows of paleæ (peristomial chætæ), one on the external margin immediately inside the papillæ, and one on the internal margin (Fig. 4).

The outer row of paleæ contains thirty-four or thirty-five thin, straight, translucent, flattened bristles, which run out into long fine points at their distal ends.

The paleæ of the inner row, of which eleven can be seen on each side, are much stouter and stronger than those of the outer row. They are of a bright yellow colour, straight, flattened, and directed forwards. The two most posterior chætæ of this row appear much smaller than the others, their tips only protruding through the skin, and they appear to be separated from the others by a considerable interval, being situated quite at the hinder end of the inner margin of the lobe. The intervening space is not, however, free from paleæ, which are present, but have not pierced the skin.

Behind the rows of paleæ (Fig. 4), on the dorsal surface of the worm are two stout, black hooks, one on each side, embedded in fleshy papillæ and curving backwards. Outside the hooks are two conical papillæ, which seem to be the two most posterior members of the rows of papillæ which line the outer margins of the peristomial lobes. They are, however, of considerably larger size than the papillæ immediately in front of them.

The inner and ventral surfaces of the peristomial lobes (Fig. 3) are covered with numerous tentacular filaments, arranged, as is usual amongst the Sabellaridæ, in transverse rows.

The mouth lies on the ventral surface, between the bases of the peristomial lobes (Figs. 1 and 3), and is almost completely surrounded by a large, hood-shaped structure. Posteriorly the mouth, including 
the hinder portion of the 'hood-shaped structure,' is bordered by a curved row of ten rounded, cushion-like lobes, and laterally there is on each side a much larger conical lobe, as in Sabellaria.* Outside this conical lobe lies the neuropodial cirrus of the first segment, and externally to this again a small rounded lobe, from in front of which the short neuropodial bristles of this segment arise.

The two tentacles are best seen from the ventral surface of the worm. They arise behind (dorsal to) the lip, and extend a little beyond the anterior ends of the peristomial lobes. The tentacles

* After the above was written I sent the specimen of Pallasia to Mr. Arnold Watson, who is at present engaged in a study of the British Sabellaridæ. Mr. Watson has kindly allowed me to print here the following valuable note explaining his views as to the nature of the structures which surround the mouth :-

"The hood-shaped structure which surrounds the mouth (well shown in Figs. 1 and 3 ) is really formed by the upper and lower lips combined; the top portion being due to the former, and the side folds to the latter. As the result of recent study of the British Sabellaridæ (S. alveolata and $S$. spinulosa) I have found that the lower lips (by means of a membranous structure winding in and out between the tentacular fans) are practically extended to the distal extremities of the peristomial lobes, while the upper lip is similarly but more directly so extended right and left, a few foldings only (less than a dozen on either side) occurring anteriorly, and each fold corresponding with the position of a single tentacular filament placed in the inner margin of the peristomial lobe. The membranes which proceed from the upper and lower lips respectively coalesce at the extremity of the lobes. The result is the formation of a ciliated channel running the length of each lobe, receiving, by means of the transverse folds, the material collected by the fans and by the internal filaments, and conveying it to the mouth of the worm, there to be used for food or for building purposes. An arrangement, similar in principle, but differing in detail, appears to exist in Pallasia.

"The hood-shaped structure, the product of the upper and lower lips combined, is common to all. Fear of causing injury by manipulation of the tentacular filaments, etc., to the specimen Pallasia, has prevented my making a satisfactory examination, but by careful posing and illumination it can be seen that the margin of the upper lip, though shallower, runs forward (and not backwards, as would be needful to form a hood), and that it is intimately connected with the first of a series of filaments which border completely the inner edge of the peristomial lobe. For the reason before given, the course of the lower lips cannot be followed, but from appearances and analogy with Sabellaria, each lip is probably connected with the inner edge of the first external fan. An avenue or channel is thus formed between the inner and outer sets of filaments, leading to and carrying material to the mouth in the way already explained.

"The main difference to be noted is, that whereas in Sabellaria there are only few inner tentacular filaments, and those at varying intervals, in Pallasia the inner margin of the lobes is by their means cempletely and compactly fenced. Viewed from the dorsal surface, these inner filaments seem to have a fan-like arrangement somewhat similar to those in the outer edge, but not quite so well defined.

"'The 'curved row of cushion-like lobes,' combined with the 'larger conical lobes,' forms the 'building organ' of the worm. They are glandular structures, and doubtless supply the cement with which the sand, stones, and shells are attached. I have seen the whole in action in Sabellaria, and by means of seetions the glandular structure of the organ has been proved. The peculiar columnar arrangement of the glands is, in Pallasia, to some extent indicated by its external appearance. In Sabellaria the glandular portion, although crenate on its edge, is not distinctly divided into cushion-like lobes. Probably the latter arrangement in Pallasia is a modification enabling the worm to deal more easily with the very bulky material used in the construction of its tube,

ARNOLD T. WATSON," 
have the same general shape as the palps of Spionidæ and Disomidæ (e.g. Pocilochotus), being D-shaped in section with the flattened (or grooved) surface, bordered by a crenate membrane.

Meyer (1888, p. 507) suggests that the peristomial lobes (Paleenträger) represent the notopodia of the first segment of the body. This view is supported by the striking resemblance between the relations of the parts in Pallasia murata and that found in Pocilochoetus, ${ }^{*}$ where the parapodia of the first segment are much enlarged and directed forwards. It may be noted in this connection that Meyer considers that the Hermellidæ are nearly related to the Spionidæ, with which family Precilochotus also is closely allied.

The neuropodial cirrus of the second segment is seen immediately behind the mouth. It consists of a flattened, triangular lobe, $\uparrow$ from in front of which a bundle of hair-like bristles arises. The notopodium of this segment is represented by two broad, flattened, forwardly directed, fin-like processes, extending transversely along the lateral surfaces of the body, and running out into two or three points. No notopodial chætæ can be seen. The notopodial cirrus of the second segment is well developed, springing from the dorso-lateral surface and falling inwards and backwards to meet its fellow of the opposite side, constituting with the latter the first of the pairs of gills with which the dorsal surface of the worm is furnished.

In the third segment the neuropodium consists of a very small, pointed lobe, from below and behind which a few short, flattened chætæ spring. There is no neuropodial cirrus. The notopodium consists of a broad, flattened, fin-like process, with a small secondary lobe or cirrus attached to the posterior angle of its dorsal surface, and provided with a row of strong, broad, flattened chætæ (paleæ) of a bright yellow colour. The notopodial cirrus forms a gill like that of the second segment, though slightly larger.

The fourth, fifth, and sixth segments are very similar in character to the third, and all have broad, strong chætæ in the neuropodia. These chætæ occur, therefore, in four segments and not in three as in Sabellaria.

In the seventh segment the parapodia take on the form which persists generally throughont the abdomen. This region comprises about forty segments, of which the last few are rudimentary, and on which the dorsal cirri (gills) persist only in the first fifteen or sixteen. The notopodia on all the segments have the form of flattened, fin-like processes, each bearing along its external margin a closely packed row of uncini. These uncini (Fig. 6) have eight teeth, of which the first is only slightly developed. The middle teeth are the longest. Two long, tendonlike filaments are attached to the lower end of each uncinus, and one

\footnotetext{
* Allen, E. J., “The Anatomy of Pœcilochætus," Quart. Journ. Micr. Sci., vol, xlviii. p. 79, + On one side of the specimen examined this lobe is bifid,
} 
such filament is also attached to a small projecting piece behind the first rudimentary tooth. The neuropodial cirri are developed on the abdominal segments as flattened, bilobed processes arising behind the bundles of neuropodial chætæ and joined to the ventral edges of the notopodia. Of the two lobes of each cirrus the internal is rounded, the external conical and pointed; the bilobed structure becomes less pronounced posteriorly. Each neuropodium has a bundle of long, hairlike chætæ, which are longest on the most posterior segments and show the structure seen in Fig. 7.

The smooth, caudal portion of the worm is devoid of appendages, excepting for three or four pairs of rudimentary neuropodial cirri on its most anterior part. The anus is terminal and is surrounded by a large, funnel-shaped membrane with a crenate margin.

Dimensions. Total length of preserved specimen, $13 \mathrm{~cm}$. (5.1 inches). Length of first segment to the tip of the peristomial lobes, $22 \mathrm{~mm}$. Length of thorax, to anterior edge of mouth, about $19 \mathrm{~mm}$. Length of abdomen, $66 \mathrm{~mm}$. Length of caudal portion, $26 \mathrm{~mm}$. Maximum breadth, not including parapodia, $10 \mathrm{~mm}$. Length of tentacles, $18 \mathrm{~mm}$.

Amongst the various species of Sabellaridæ (Hermellidæ) which have been described, the two species which most nearly resemble that now found at Plymouth are Sabellaria (Pallasia) Giardi, McIntosh (from Port Jackson, Sydney), which McIntosh thinks may be identical with Kinberg's Lygdomis indicus, and sabellaria (Pallasia) lavispinis, Grube (from Upolu and Ascension). The three species P. lavispinis, $P$. Giardi, and P. murata form a distinct group of the genus Pallasia characterised by the deep division of the peristomial lobes (a character found also in P. Johnstoni, McIntosh), by the straight, slender and pointed paleæ of these lobes, and by the fact that the dorsal chætæe of four segments (Segts. 3, 4, 5, and 6) have the modified, stout, flattened form, instead of this modification being confined to three segments only.

The following table gives an indication of some of the points in which the three species differ from one another:-

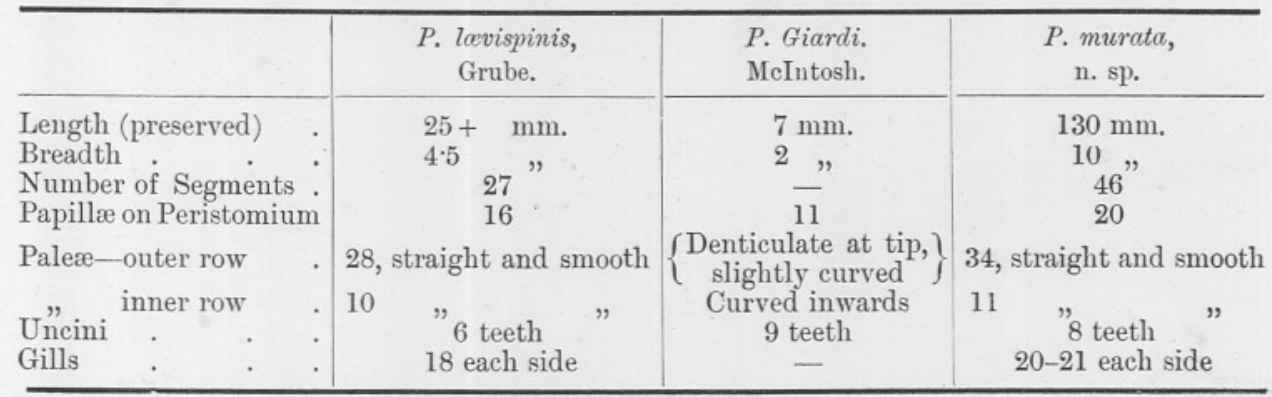




\section{LITERATURE.}

(Family Sabellaride.)

1863. Baird.-Proceed. Zool. Soc. London, p. 109.

1865. Quatrefages,-Hist. Nat. Annelés, T. ii. pp. 308-325. References to previous literature on the subject will be found here.

1866. KinberG.--Annulata Nova. Öfvers k. Vetensk. Akad. Förhandl 1866. p. 350 .

1869. Grube---Ueber die Goldkrönchen (Sabellarien oder Hermellen). Jahresb. Schles. Gesell für 1869, pp. 69 and 70.

1877. Grube.-Annelidenausbeute von S.M.S. Gazelle. Monatsber. König. Akad. Wissen. Berlin, p. 542.

1878. Grube.-Annulata Semperiana, p. 217.

1882. Haswell--Proceed. Linn. Soc. N.S.W., vii. p. 634.

1885. McInтosh.-Challenger Report, xii. pp. 414-422.

1887-1888. Meyer, E.-Studien über den Körperbau der Anneliden. Mitth. Zool. Stat. Neapel., vii. p. 592, viii. p. 462.

1897. Ehlers. - Hamburger magelhaenische Sammelreise, p. 124.

1900. Pratт.-A Collection of Polychrta from the Falkland Islands. Mem. Manchester Lit. and Phil. Soc.

\section{EXPLANATION OF PLATE X.}

Illustrating Dr. E J. Allen's paper on "Pallasia murata, n. sp. : a new British Sabellarian."

Fig. 1. Pallasia murata, ventral view. Natural size.

Fig. 2. " " dorsal view. Natural size.

Fig. 3. Anterior segments, ventral view. $\times 2$.

Fig. 4. " " dorsal view. $\times 2$.

Fig. 5. Tube of Pallasia murata. Natural size.

Fig. 6. Uncinus.

Fig. 7. Neuropodial chæta of abdomen. 